A N N A L E S

UNIVERSITATIS M A R A E C URIE-SKŁODOW S A

LUBLIN - POLONIA

VOL. XXXI, 2

SECTIO J

2018

Uniwersytet Marii Curie-Skłodowskiej w Lublinie. Wydział Pedagogiki i Psychologii

\title{
ANNA LADA
}

ORCID: 0000-0002-4625-0406

anna.lada@poczta.umcs.lublin.pl

Jakość życia seniorów

Quality of Seniors' Life

\section{STRESZCZENIE}

Przed Europą stoi wielkie wyzwanie społeczne. Seniorzy w krajobrazie społecznym są jego nieodłącznym i istotnym elementem, jednak jeszcze nigdy dotąd nie stanowili tak licznej grupy, dlatego ważna stała się jakość życia osób starszych. Niniejszy artykuł to głos w dyskusji na temat starzejącego się społeczeństwa i jakości życia seniorów. Ma na celu przybliżenie znaczenia jakości życia oraz stanowi analizę poszczególnych elementów (takich jak zdrowie, kontakty z rodziną, aktywny udział w życiu społecznym, szanse na rozwój czy możliwości realizowania własnych planów i zamierzeń), z uwzględnieniem potrzeb, możliwości i wartości ludzi starszych. Seniorzy dzięki swojemu doświadczeniu i wartościom przekazywanym młodszym pokoleniom są ogromnym kapitałem z nieocenionymi zasobami wiedzy, mądrości i umiejętności. Szczegółowa charakterystyka wybranych elementów tworzących jakość życia pozwoli w pełniejszy sposób zrozumieć problemy i podjąć kroki w celu optymalizacji jakości życia starszego pokolenia.

Slowa kluczowe: senior; gerontologia; jakość życia; starzenie się

\section{WPROWADZENIE}

Społeczeństwo XXI w. to bez wątpienia społeczeństwo starzejące się. Jak wynika z wielu analiz, średni wiek życia Polaków się wydłuża. Obecnie kobiety żyją przeciętnie 80 lat, a mężczyźni - 72 lata. Prognozy wskazują, iż w 2035 r. wiek kobiet może osiągnąć 84 lata, natomiast mężczyzn - 77 lat. Opracowania przygotowane przez Eurostart dla 25 krajów unijnych oraz Bułgarii i Rumunii wskazują, że do 2035 r. liczba ludności w krajach UE zwiększy się o 5,1\%, natomiast 
w Polsce zmniejszy się o 5,2\%. Jednocześnie przewiduje się, że seniorów do 80. roku życia będzie o $88 \%$ więcej w krajach wspólnoty i o $143 \%$ więcej w Polsce w porównaniu do stanu aktualnego (Steuden 2014, s. 17-18).

Mając na uwadze tę tendencję, należy ze szczególną uwagą przyjrzeć się seniorom oraz jakości ich życia. Samo poczucie bezpieczeństwa to dla osób starszych niewystarczający faktor godnego funkcjonowania społecznego i indywidualnego. Przy stale wydłużającym się wieku życia, należy z wyjątkową atencją i troską pochylić się nad seniorami, by czuli się potrzebni, przydatni, akceptowani oraz szanowani w społeczeństwie i rodzinie. Tym samym jakość życia seniorów staje się ważnym elementem aktywnej polityki społecznej i rodzinnej właściwie wszystkich krajów europejskich.

\section{JAKOŚĆ ŻYCIA - ZAKRES DEFINICYJNY}

Jakość życia to termin wieloznaczny, często używany zarówno w dyskusjach naukowych, jak i w życiu codziennym. Jak słusznie zauważa E. Skrzypek:

(...) jakość życia człowieka to nie tylko byt w sensie fizycznym, ale także możliwości wzbogacenia ducha, umysłu, możliwość kształcenia, a także twórczość i kreatywność. Jakość życia człowieka to suma jego starań, zmagań, walki toczonej często z samym sobą, to umiejętność dokonywania trafnych wyborów, to także zdolność do kompromisów, to przede wszystkim umiejętność podejmowania decyzji i przyjmowania ich konsekwencji z całą odpowiedzialnością (Skrzypek 2001, s. 1).

Według Światowej Organizacji Zdrowia (The World Health Organization Quality of Life assessment... 1995, s. 1403-1409) jakość życia to „indywidualny sposób postrzegania przez jednostki jej pozycji życiowej w kontekście kulturowym i systemu wartości, w którym żyje, oraz w odniesieniu do zadań, oczekiwań i standardów wyznaczonych uwarunkowaniami środowiskowymi”. Z kolei A. Bańka (2005, s. 25) twierdzi, że jest to „efekt rozwoju jednostki, czyli skutek procesu konstruowania standardów porównań dla osiągalnych w czasie informacji, z jednej strony, oraz wypadkowa rozłożonego w czasie procesu konstruowania sądów o życiu, będących mentalnymi reprezentacjami życia i regulatorami procesu przetwarzania napływających informacji”. Autor (Bańka 2005, s. 25-32) zwraca uwagę na fakt, iż człowiek oceniający jakość życia czerpie z czterech podstawowych źródeł: przeszłych doświadczeń, teraźniejszych przeżyć, oczekiwań związanych z przyszłością oraz opinii społecznej.

Koncepcja jakości życia jest złożona, dlatego definiując jej składowe, należy uwzględnić dobrostan fizyczny, materialny, społeczny, emocjonalny oraz zadowolenie z własnej produktywności. Model jakości życia Centrum Promocji Zdrowia Uniwersytetu w Toronto zakłada trzy kluczowe sfery jakości życia: 
- istnieć (psychicznie, fizycznie, duchowo),

- przynależeć (fizycznie, społecznie, socjalnie),

- stawać się (w rozwoju, wypoczynku, działaniu) (Dziurowicz-Kozłowska 2002, s. 77-99).

Taki obraz definiowania jakości życia ukazuje wieloczynnikowy charakter tego zagadnienia. K. Baumann, analizując literaturę przedmiotu, zdefiniowała 13 faktorów warunkujących i wpływających na jakość życia. Są to:

- dobrostan fizyczny (energia, działanie, funkcjonalność; seksualność; jakość opieki zdrowotnej; brak bólu; zachowanie zmysłów, np. słuch, wzrok; odpowiednia ilość czasu na wypoczynek i sen),

- dobrostan finansowy i materialny (niezależność finansowa; zabezpieczenie finansowe; przychody z różnych źródeł; posiadanie dóbr materialnych, np. mieszkanie, samochód),

- dobrostan osobisty (zdrowie psychiczne; szczęście; samoocena; godność; tożsamość; ciągłość rozwoju; wygląd zewnętrzny/obraz siebie; pamięć; kontrola nad własnym życiem; niezależność; duchowość; brak stresu; miłość; edukacja; łatwość adaptacji; możliwość wyboru),

- dobrostan społeczny (rodzina; przyjaźń; bogate życie towarzyskie; wsparcie społeczne),

- życiowa satysfakcja (spełnienie; pełnia życia; kreatywność; pogoda ducha),

- cel życia (altruizm; zaangażowanie się, udział w życiu innych; produktywny, owocny proces starzenia się),

- dobrostan estetyczny (czas wolny; zainteresowania, hobby; kontakt z muzyką, sztuką, literaturą),

- wesołość/radość (małe i duże przyjemności; uciecha, zabawa),

- dobrostan moralny (czyste sumienie),

- radość życia (poczucie, że warto było żyć),

- duchowość (osobiste wierzenia/przekonania religijne),

- życie teraźniejszością (elementarność; prostota; naturalność; wolność od zaabsorbowania przeszłością i przyszłością),

- koniec życia (jakość umierania; poczucie kontroli; jakość opieki - minimalizacja bólu i cierpienia) (Baumann 2006, s. 169-170).

W 2002 r. Polska przyjęła założenia Międzynarodowej Strategii Działania w Kwestii Starzenia się Społeczeństw - tzw. Plan Madrycki, który w konsekwencji wprowadzania swoich zapisów upatruje szansę na poprawę jakości życia osób starszych. W planie tym zostały sformułowane najważniejsze obszary działania społecznego wobec ludzi starszych. Syntezując zapisy zawarte w dokumencie, zespół P. Błędowskiego scharakteryzował sieć działań na rzecz seniorów. Są to:

- budowa społeczeństwa przyjaznego ludziom w każdym wieku,

- zapewnienie ciągłości rozwoju w starzejącym się świecie dzięki: ograniczaniu rozmiarów ubóstwa wśród ludzi starych, sprzyjaniu produktywne- 
mu starzeniu się, uwzględnianiu problemów związanych z zatrudnieniem coraz starszych pracowników,

- edukacja osób starszych, wyrównywanie dysproporcji w rozwoju poszczególnych regionów, umacnianie więzi międzypokoleniowych i przestrzeganie praw człowieka w odniesieniu do osób starszych i niesamodzielnych,

- dbałość o dobry stan zdrowia i dobre samopoczucie osób starszych,

- tworzenie korzystnych i sprzyjających warunków życia dla osób w każdym wieku w następstwie zagwarantowania ochrony socjalnej i wsparcia materialnego oraz poprawy warunków mieszkaniowych i wyposażenia mieszkań,

- zapewnienie opieki dla osób niesamodzielnych oraz ochrony przed naruszaniem praw osób starszych i przemocą w stosunku do nich,

- promocja solidarności międzypokoleniowej i pozytywnego wizerunku ludzi starych (Błędowski i in. 2012, s. 11).

Jakość życia określa perspektywę pomyślnego starzenia się i starości. Głównym czynnikiem definiującym jakość życia jest satysfakcja życiowa (zadowolenie z życia). „Koncepcja pomyślnego starzenia się oparta jest na definiowaniu szczęścia jako uniwersalnego celu dążeń człowieka oraz silnej potrzeby na wszystkich etapach życia" (Chabior, Fabiś, Wawrzyniak 2017, s. 118). Satysfakcja życiowa z kolei jest określana mianem szczęścia, dobrego samopoczucia.

\section{STAROŚĆ - ZAKRES DEFINICYJNY}

Starzenie się i starość to zagadnienia szeroko poruszane w literaturze przedmiotu. Gerontologia stała się jedną z najprężniej rozwijających się dyscyplin naukowych, a wszystko za sprawą procesów demograficznych zachodzących we współczesnym społeczeństwie.

Nazwana trzecim wiekiem, starość to schyłkowy etap życia człowieka, łączący się z przezwyciężaniem większości kryzysów rozwojowych.

Starość to trudny etap życia człowieka. I chociaż jest naturalną koleją życia, towarzyszy jej strach przed niedomaganiami, niedołężnością i samotnością. Nazywana jesienią albo wieczorem życia, wymaga pogodzenia się z faktem i przygotowania się do niego. Nie da się zapomnieć, że nieodzownym kresem życia człowieka jest śmierć, która często napawa smutkiem i lękiem. Stworzenie warunków godnego dopełnienia życia to wyzwanie stojące przed każdym z następujących pokoleń. Empatia i współczucie dla seniorów dotkniętych różnorodnymi dolegliwościami, ich bezradności i niekiedy upokarzającego poczucia bycia ciężarem, pomaga wyciszyć przygnębiające myśli, by pogodnie i z nadzieją przekroczyć smugę cienia. Pomoc w akceptacji i zrozumieniu ostatniego etapu życia człowieka pozwala z pokorą i szacunkiem przygotować się i przyjąć to, co nieuniknione (Zych [red.] 2014, s. 10). 
Starość, zgodnie z definicją Światowej Organizacji Zdrowia, rozpoczyna się po 60. roku życia. Organizacja Narodów Zjednoczonych jednak przesunęła granicę wieku o 5 lat, wskazując, że jest to 65 . rok życia. Starzenie się należy rozpatrywać w płaszczyźnie trójstronnej - w kontekście zmian biologicznych, psychologicznych i społecznych. Wiek biologiczny definiuje i określa ogólną sprawność człowieka, żywotność organizmu, sprawność i jego funkcjonowanie. Wiek psychiczny z kolei określa funkcje intelektualne i percepcyjne. Wiek społeczny natomiast wskazuje na udział w życiu społecznym jednostki.

Zgodnie z propozycją W. Pędicha (1996, s. 7) starość można podzielić na trzy okresy: wczesną starość (od 60. do 74. roku życia), późną starość (od 74. do 89. roku życia) i starość sędziwą lub długowieczność (po 90. roku życia). J. Kocemba (2000, s. 108) również wyróżnił trzy okresy starości, ale inaczej je scharakteryzował. Pierwszy okres to tzw. trzeci wiek (od 60. do 75. roku życia), drugi etap to starość dojrzała (od 75. do 90. roku życia), a trzeci to długowieczność (po 90. roku życia). Jak wskazuje J.K. Wawrzyniak (2017, s. 44), w ujęciu psychologicznym także wyróżnia się trzy etapy starości: przedpole starości, kiedy człowiek przygotowuje się do emerytury (od 60. do 67. roku życia); początek starości społecznej, związany z przejściem na emeryturę (po 67. roku życia) - w tym czasie senior staje się użytkownikiem czasu wolnego, poszukuje i podejmuje satysfakcjonującą go aktywność (od 67. do 75. roku życia); starość socjalną, kiedy senior przyjmuje rolę biorcy i kontemplatora (powyżej 75. roku życia).

Według amerykańskiej badaczki S. Reichard wyróżnia się pięć typów przystosowania się w starszym wieku, czyli pięć postaw ludzi starszych w stosunku do świata, do siebie i do własnej starości:

- postawa „konstruktywna” - polegająca na tym, że człowiek ma pogodny nastrój i jest wewnętrznie zrównoważony, ma również satysfakcjonujące go kontakty międzyludzkie, potrafi cieszyć się życiem, jest tolerancyjny, z poczuciem humoru. Człowiek reprezentujący taką postawę akceptuje własną starość i fakt odejścia na emeryturę. Ewentualność śmierci traktuje jako naturalne zdarzenie niewywołujące rozpaczy i żalu. Taki człowiek jest optymistycznie zorientowany na przyszłość, bowiem ma dodatni bilans i może liczyć na pomoc ze strony otoczenia społecznego,

- postawa „zależności” cechuje osoby wykazujące bierność i zależność od innych, zależność od partnera małżeńskiego lub swego dziecka. Postawa taka cechuje ludzi niemających zbyt wysokich aspiracji życiowych i chętnie wycofujących się z roli zawodowej. Rodzina jest im potrzebna do zapewnienia poczucia bezpieczeństwa i umożliwia utrzymanie harmonii wewnętrznej. Osoby reprezentujące taką postawę nie przejawiają ani objawów braku zrównoważenia emocjonalnego, ani wrogości i lęków,

- postawa „obronna” jest charakterystyczna dla ludzi „opancerzonych psychicznie”, przesadnie opanowanych, sztywnych w swych nawykach i przyzwyczajeniach, zaabsorbowanych aktywnością zawodową, samowystarczalnych. Ich poglądy i postawy są konwen- 
cjonalne, unikają wypowiadania własnych sądów, z trudem mówią o swoich problemach życiowych lub rodzinnych, bardziej zajęci są życiem zewnętrznym niż własnymi przeżyciami. Odczuwają lęk przed śmiercią i niedołęstwem, który starają się maskować wzmożoną aktywnością i stałym zaabsorbowaniem zewnętrznymi czynnościami. W ich postawie jest lekkie znerwicowanie i okazywanie zazdrości wobec młodych ludzi,

- postawa „wrogości do otoczenia” jest charakterystyczna dla „starych - gniewnych”, którzy są agresywni, wybuchowi i podejrzliwi, a także mają tendencję do przerzucania na otoczenie - innych ludzi, instytucje lub układy społeczne - własnych pretensji oraz przypisywania im winy za wszelkie niepowodzenia. Cechuje ich brak realizmu oraz traktowanie starości jako okresu wyrzeczeń i ubóstwa, zniedołężnienia i utraty sił. Zazdroszczą młodym ich wieku, nie mogą się pogodzić ze starością, buntują się przeciwko niej, a zarazem odczuwają lęk przed śmiercią,

- postawa „wrogości do siebie” charakteryzuje ludzi o wyraźnie ujemnym bilansie życiowym, którzy unikają powracania do wspomnień życiowych, ponieważ w ich życiu było wiele niepowodzeń i trudności. Reprezentują ją ludzie nieaktywni i mało zaradni. Nie buntują się oni przeciwko swojej starości, ale biernie przyjmują to, co zsyła im okrutny los. Niemożność zaspokojenia potrzeby miłości jest powodem przeżywania depresji. Ludzie o takiej postawie mają żal i pretensje do samych siebie. Towarzyszy tej postawie poczucie osamotnienia i zbędności. Dość realistycznie oceniają swoje starzenie się, zaś śmierć traktują jako wyzwolenie od nieszczęśliwej egzystencji (za: Kotlarska-Michalska 2000, s. 150).

Wskazane postawy w naturalny sposób przyczyniają się do wartościowania przez seniora swojego życia. Zgodnie z dominującą postawą weryfikuje on swoje dotychczasowe osiągnięcia, wpływając tym samym na ocenę jakości życia.

Współcześnie starość stała się wyzwaniem w społeczeństwach opartych na pracy zarobkowej i w krajach rozwijających się. Sytuacja demograficzna wymusiła zmianę polityki społecznej, zwrócenie się ku potrzebom osób starszych, stworzenie dla nich miejsca w życiu społecznym i zadbanie o jakość ich życia. Jak słusznie zauważa M. Szyszkowska (2014, s. 26): „Wiele wartościowych osób - a w tym sędziwych - mogłoby mieć pożyteczny wpływ na nasze społeczeństwo, gdyby byli właściwie oceniani przez tych, którzy mają władzę polityczną i media w swoich rękach. Całkowicie jest niezrozumiałe, dlaczego data urodzenia hamuje udział w życiu publicznym".

\section{JAKOŚĆ ŻYCIA SENIORÓW}

Seniorzy jakość swojego życia definiują i oceniają przez pryzmat zaspokajania potrzeb, wśród których główną rolę odgrywają: zdrowie, kontakty z rodziną, aktywny udział w życiu społecznym, szanse na rozwój czy możliwość realizowania własnych planów i zamierzeń. 
Stan zdrowia seniorów to kluczowy czynnik kształtujący ich obraz i ocenę jakości życia. Jak twierdzi B. Bień:

(...) zdrowie seniorów z jednej strony zależy od tempa naturalnego osobniczo zmiennego procesu starzenia się, z drugiej zaś jest następstwem chorób, w tym zależnych od wieku, przebytych urazów, wypadków, jak również przeszłych i bieżących oddziaływań środowiska. Ocena zdrowia, oparta jedynie na badaniach klinicznych, nie jest w stanie objąć ani wyrazić całego zakresu i wewnętrznej złożoności elementów składających się na poczucie zdrowia w indywidualnych przypadkach, a tym bardziej odnosić się do populacji (Bień 2002, s. 35).

W przypadku kłopotów ze zdrowiem charakterystyczna dla pacjentów geriatrycznych jest wielochorobowość (polipatologia), czyli stan, w którym u pacjenta diagnozuje się kolejno kilka chorób wzajemnie na siebie oddziałujących. Jak konstatuje K. Wieczorowska-Tobis (2011), w wyniku powstałego stresu i braku możliwości przystosowania się u seniora występuje tzw. efekt domina. „Oznacza on, że w przypadku uszkodzenia jednego narządu ryzyko zmian wielonarządowych jest znaczne. Podobnie jak w przypadku kostek domina, złamanie homeostazy w obrębie pierwszego narządu powoduje reakcję lawinową, która może kończyć się niewydolnością wielonarządową" (Wieczorowska-Tobis 2011, s. 20). Taka sytuacja z kolei może przyczynić się do niepełnosprawności seniorów, która jest definiowana przez A. Wilmowską-Pietruszyńską jako sytuacja, w której „osoby nie mogą częściowo lub całkowicie zapewnić sobie możliwości normalnego życia indywidualnego i społecznego na skutek wrodzonego lub nabytego upośledzenia sprawności fizycznych lub psychicznych" (Wilmowska-Pietruszyńska 2012, s. 139). J. Car uważa, że „głównymi przyczynami niepełnosprawności oraz ograniczeń mobilności, czyli możliwości poruszania się, są choroby układu krążenia oraz choroby układu ruchu, następnie schorzenia neurologiczne, choroby narządu wzroku, choroby narządu słuchu i inne schorzenia" (Car i in. 2004, s. 49).

Kontekst zdrowia seniorów jest szeroko omawiany w gremiach naukowych, społecznych i pomocowych. Starość jako integralna część ludzkiego życia wiąże się z pewnymi ograniczeniami, dysfunkcjami czy chorobami. Wartością jest sposób radzenia sobie w danej sytuacji. K. Osińska (1980, s. 43-56) niemal cztery dekady temu wyróżniła osiem przeciwstawnych par postaw wobec choroby. Pierwszą grupę stanowią postawy altruistyczne (twórcze), które bez wątpienia wpływają na poprawę jakości życia seniorów. Wśród nich wyróżniła takie postawy, jak:

- dawca: człowiek, mimo własnego cierpienia, umie dzielić się życzliwością i radością, dostrzega potrzeby drugiego człowieka i jego sytuację,

- samarytanin: człowiek, który jest zatroskany o los własny i innych, z rozwagą i zainteresowaniem słucha i stara się pomóc,

- pomocnik: akceptując własną chorobę, stara się aktywnie uczestniczyć w procesie leczenia i rekonwalescencji, 
- konspirator: człowiek cierpiący, ale starający się ukryć przed innymi swój stan, zaangażowany we własne leczenie,

- poszukiwacz: obserwuje, jak choroba wpływa na niego i innych, stara się znaleźć akcenty, w których może się realizować i rozwijać,

- żołnierz: godnie znosi cierpienie, dodając otuchy innym, znajdującym się w podobnej sytuacji,

- artysta: cierpiąc, szuka refleksji, wydźwięku artystycznego lub filozoficznego w swojej chorobie,

- bohater: bezinteresowny, wielkoduszny, mimo swojej choroby zaangażowany w pomaganie innym.

Z drugiej strony znajduje się osiem przeciwstawnych, egoistycznych (pasożytniczych) postaw, które nie mają pozytywnego wpływu na ocenę życia jako satysfakcjonującego czy przynajmniej zadowalającego seniorów. Wśród nich wyróżnia się: biorcę, hipochondryka, malkontenta, zasłużonego, statystę, żebraka, zawodowca, świętoszka.

Stan zdrowia warunkuje autonomię życiową. Aby ten aspekt jakości życia był oceniany na możliwie najwyższym poziomie, należałoby zwrócić szczególną uwagę na promocję profilaktyki geriatrycznej, leczenie seniorów oraz możliwości terapeutyczne, rehabilitacyjne i wspomagające. W obecnej dobie rozwoju technologicznego, postępu medycyny i niezliczonych badań w zakresie farmakologii, dbanie o zdrowie seniora wydaje się łatwiejsze niż kiedykolwiek wcześniej. Tymczasem świadomość starszego pokolenia dotycząca profilaktyki wielu chorób i zaburzeń - mimo powszechnej opinii społeczeństwa, jakoby seniorzy nie stronili od wizyt lekarskich - jest znikoma. Taki stan rzeczy może wynikać z faktu, iż dbałość o zdrowie wiąże się bez wątpienia z czynnikiem finansowym osób starszych. Seniorzy często mają problem z wykupieniem koniecznych lekarstw czy suplementów. Mimo niejednokrotnie trudnej sytuacji finansowej coraz częściej z wielką atencją pochylają się nad własnym zdrowiem. Liczne programy wspomagające aktywność osób starszych, kluby zrzeszające osoby, które tańczą zumbę, ćwiczą aerobik czy uprawiają nordic walking sprawiają, że z dnia na dzień wzrasta liczba osób starszych zainteresowanych ruchem. Seniorzy, zauważając ogromny pozytywny wpływ aktywności fizycznej na ich zdrowie, chętniej uczestniczą w takich zajęciach. Światowa Organizacja Zdrowia sugeruje, aby programy dotyczące aktywności fizycznej przeznaczone dla osób starszych uwzględniały następujące reguły: zajęcia mogą mieć charakter indywidualny i grupowy; powinno się stosować różne formy ćwiczeń: elementy rozciągania (stretching), ćwiczenia aerobikowe, relaksację; ćwiczenia powinny obejmować formy łatwe lub o umiarkowanym stopniu trudności: spacer, taniec, pływanie, jazda na rowerze, gimnastyka; składowe ćwiczeń powinny obejmować trening mięśni - ćwiczenia wytrzymałościowe, trening równowagi i „elastyczności”; ćwiczenia powinny sprawiać radość i powodować odprężenie; powinny być prowadzone regularnie, 
jeśli to możliwe - codziennie (Kaczmarczyk, Trafiałek 2007, s. 117-118). Dzięki promocji tego typu działań jakość życia seniorów może ulec znaczącej poprawie bez konieczności lokowania dużych zasobów finansowych.

Kolejnym elementem warunkującym ocenę jakości życia seniorów są relacje z rodziną i przyjaciółmi. To rodzina, jako podstawowa grupa społeczna, jest dla człowieka pierwszym środowiskiem, w którym funkcjonuje. Aktywność życiowa seniorów wskazuje na wiele czynników wpływających na tę ocenę dzięki istniejącym więziom emocjonalnym w rodzinie. Wśród nich można wyróżnić: strukturę rodziny, więzi międzypokoleniowe, sytuację materialną i zdrowotną oraz wzajemną pomoc i zrozumienie (Chabior 2014a, s. 51-54). Rodzina jest tym środowiskiem, które w pierwszej kolejności stwarza swoim członkom możliwości rozwoju i zaspokaja ich potrzeby. Jak wskazuje A. Chabior:

(...) rodzina stanowiła, stanowi i - jak można zakładać - stanowić będzie specyficzny układ relacji międzyosobowych i wewnątrzrodzinnej wzajemności, wsparcia i pomocy. Środowisko rodzinne to także miejsce wzajemnej wymiany usług. Starsi rodzice chętnie przyjmują pomoc od swoich dzieci i odwrotnie, dzieci także przyjmują pomoc ze strony starszych, lecz jeszcze sprawnych i mobilnych rodziców (Chabior, Fabiś, Wawrzyniak 2017, s. 138).

Nieoceniona i niezwykle ważna jest rola seniorów także w życiu najmłodszych. Zmiany społeczne, demograficzne czy technologiczne spowodowały, iż rola babci i dziadka również ewoluowała. Na zmiany w sposobach realizowania tych ról, zgodnie ze spostrzeżeniami A. Chabior, ma wpływ kilka kluczowych czynników:

(...) uwarunkowania makrostukturalne o charakterze biologiczno-demograficznym, takie jak wydłużenie okresu życia i towarzyszące temu wydłużanie się czasu zachowania wysokiej sprawności funkcjonalnej i psychofizycznej dziadków; czynniki społeczno-kulturowe, takie jak: ewolucja obyczajów i sposobu postrzegania zadań wynikających z roli babci/dziadka, ale też pozycji społecznej osób starszych, migracja, wzrost poziomu wykształcenia osób starszych, ich aktywność zawodowa i aktywizacja społeczna, aktywizacja zawodowa kobiet; czynniki rodzinne, a wśród nich: linia pokrewieństwa, struktura rodziny, wiek i stan zdrowia dziadków, wiek wnuków, status zawodowy rodziców, miejsce i sposób zamieszkiwania, częstotliwość i charakter kontaktów wnuków z dziadkami, poczucie zadowolenia lub niezadowolenia z życia osób starszych oraz ich stanu psychofizycznego, wreszcie pozycja seniora w rodzinie i zgoda lub ewentualnie jej brak na podjęcie i pełnienie roli babci/dziadka (Chabior, Fabiś, Wawrzyniak 2017, s. 145).

Rola dziadków w życiu wnuków, ale i w życiu całej wielopokoleniowej rodziny, wyraża się w tym, że:

- scalają rodzinę, stanowią źródło mądrości życiowej, pokazują sens opierania swojego życia na istotnych wartościach, pomagają odkryć sens życia i formować tożsamość, 
- ukazują ciągłość rodziny, powiązanie między jej przeszłością a teraźniejszością, są źródłem poczucia zakorzenienia i ciągłości pokoleniowej, stają się naturalnymi nauczycielami historii, dbają o pielęgnowanie rodzinnych tradycji,

- zabiegają, by zachować rodzinę jako całość,

- pomagają rodzicom w wychowaniu dzieci i opiece nad nimi, a także często udzielają wsparcia instrumentalnego i rzeczowego, np. w trudnej sytuacji finansowej,

- są źródłem wsparcia, bliskości i bezwarunkowej akceptacji dla wnuków, negocjatorami w sporach z rodzicami, pomagają dzieciom zrozumieć zachowanie rodziców (Chabior, Fabiś, Wawrzyniak 2017, s. 148).

To właśnie możliwość niesienia pomocy najbliższym, opiekowania się wnukami czy angażowania się w życie dzieci stanowi dla seniorów ważny wymiar wpływający na jakość ich egzystencji. Jak wskazuje J. Maćkowicz:

Doświadczenie, będące rezultatem zaangażowania dziadków w wychowanie wnuków, kształtuje szczególny rodzaj więzi, korzystnej dla obu stron. Jest to skarb cenny zarówno dla wnuka, bowiem wszystkie wartości moralne i edukacyjne uzyskane od dziadków pozostają w nim i procentują w życiu dorosłym, ale także dla starszego pokolenia, które czerpie również z tych relacji energię, świeżość oraz bogactwo różnorodnych przeżyć i wzruszeń (za: Chabior, Fabiś, Wawrzyniak 2017).

Zmiany zachodzące we współczesnym społeczeństwie sprawiły, iż na rynku usług edukacyjnych dla seniorów pojawiła się Szkoła SuperBabci i SuperDziadka. To miejsce dla tych wszystkich osób, którym brakuje pomysłów na zabawę i aktywne spędzanie czasu z wnukami. Założycielką placówki jest Z. Zaorska - babcia i pedagog, której bliski jest los seniorów oraz jakość ich życia. Dzięki temu przedsięwzięciu seniorzy z większą otwartością i śmiałością angażują się w opiekę nad wnukami, ukazując im wartości płynące z życia w wielopokoleniowym środowisku.

Fakt, że seniorzy są potrzebni i wartościowi w najbliższym dla nich środowisku sprawia, iż czują się potrzebni również w środowisku lokalnym. Wskutek tego potrafią się angażować w życie wspólnoty, są aktywni i twórczy w różnych grupach wsparcia, widzą sens i mają świadomość oddziaływania kontaktów międzyludzkich, dbają o różne relacje.

Seniorzy stanowią ważny element kreujący społeczeństwo. Ich aktywność, prowadzona na wielu polach, jest związana $\mathrm{z}$ większą ilością czasu wolnego, ale też z wyższą świadomością i chęcią uczestniczenia w życiu środowiska lokalnego.

Aktywność jest formą działalności ludzkiej nakierowanej na osiągnięcie celu i zaspokojenie potrzeby, sprzyja zachowaniu sprawności duszy i ciała, pozytywnej samoocenie, zapobiega poczuciu pustki oraz osamotnienia. Aktywność pomaga seniorom przystosować się do rzeczywistości, uczy ich radzenia sobie w nowych dla nich sytuacjach, wykorzystywania osiągnięć techniki i cywilizacji, wreszcie do korzystania z życia (Chabior 2014b, s. 83). 
Wiele czynników ma wpływ na podejmowanie aktywności w środowisku. Jak konstatuje M. Dzięgielewska, najczęściej w literaturze wymienia się:

- wykształcenie - im wyższe wykształcenie, tym poziom aktywności wyższy,

- wpływ środowiska rodzinnego - aktywność jest uzależniona od osobowości, rodziny, pochodzenia, a także od kontaktów w ramach bliższej i dalszej rodziny,

- stan zdrowia i poziom kondycji fizycznej,

- płeć - kobiety stanowią większość wśród emerytów i to one częściej podejmują aktywność,

- miejsce zamieszkania (wieś, miasto), co wiąże się z ofertą dla seniorów,

- wpływ instytucji kulturalnych w miejscu zamieszkania (Dzięgielewska 2006, s. 162).

Aby scharakteryzować rodzaje aktywności seniorów w czasie wolnym, M. Halicka i J. Halicki (2002, s. 207) zaproponowali typologię, która dzieli aktywność seniorów na trzy grupy:

- rekreacyjno-hobbystyczna: spacery, ćwiczenia fizyczne, praca w ogrodzie czy na działce, zajęcia związane z zainteresowaniami i hobby (malarstwo, melomania, rękodzieło, wychodzenie do teatru, galerii, na koncert, do kina),

- receptywna: aktywności podejmowane w warunkach domowych (oglądanie telewizji, słuchanie radia, czytanie gazet i książek),

- zorientowana publicznie: działalność społeczna, polityczna, parafialna, integracyjna. Są to różnorodne działania, zwłaszcza o charakterze towarzyskim, naukowym, szkoleniowym, non-profit czy podnoszącym konkretne umiejętności.

W podobny sposób działania seniorów scharakteryzowała M. Dzięgielewska (2006), wyróżniając również trzy rodzaje aktywności: samotniczą (oglądanie telewizji, czytanie, hobby, rozwijanie zainteresowań itp.), nieformalną (kontakty z rodziną, przyjaciółmi, sąsiadami itp.), formalną (udział w organizacjach społecznych, polityce, praca na rzecz środowiska lokalnego itp.).

Aktywne uczestnictwo w życiu społecznym umożliwiają różnorodne instytucje i placówki wspierające osoby starzejące się. Jedną z takich form aktywności są kluby seniora.

Najważniejszym celem ich działania jest umożliwienie osobom starszym korzystnego i przyjemnego spędzania czasu wolnego. Poza tym kluby stanowią płaszczyznę, na której rozwija się życie towarzyskie i kulturalne. Członkowie klubów uczestniczą w oferowanych formach w miarę swoich sił i możliwości. Wśród najczęściej występujących form działalności klubowej wymienia się upowszechnianie różnych form edukacyjnych, kół hobbistycznych, prelekcji, odczytów oraz amatorską działalność artystyczną (Kutyła 2012, s. 55).

Inną formą aktywności seniorów jest wolontariat podmiotowy, polegający na tym, że seniorzy świadczą działania pomocowe na rzecz innych. Dzięki pra- 
cy wolontarystycznej otwierają się oni na drugiego człowieka oraz przekraczają własne słabości i ograniczenia. Wolontariat daje warunki do rozwoju, twórczości, kreatywności i altruistycznej pracy na rzecz słabszych i potrzebujących. Ta forma aktywności ma niebagatelny wpływ na jakość życia seniorów, ponieważ oprócz samej wartości pomagania niesie ze sobą ważną dla starszych osób informację, iż są potrzebni, ważni i użyteczni społecznie. Wiele inicjatyw aktywności społecznej ma wymiar działań lokalnych skierowanych do konkretnej grupy odbiorców. Niezależnie jednak od zasięgu wszystkie działania wspierają i mobilizują seniorów do czynnego uczestnictwa w życiu społecznym.

Aktywność seniorów ma też odzwierciedlenie w działaniach o charakterze edukacyjnym. Specjalnie dla tej grupy powstało wiele instytucji świadczących usługi szkoleniowe czy edukacyjne. Ich zadaniem, poza podstawowym - związanym z przekazywaniem wiedzy, jest integracja społeczna. Warto mieć na uwadze to, iż senior uczący się: wykorzystuje poznane treści w życiu codziennym; jest zdrowszy fizycznie; jest bardziej elastyczny i otwarty; wyzbywa się lęków; umie dopasować tempo pracy do własnych możliwości; jest chętny do działania i zdyscyplinowany. Ważną rolę w tym zakresie odgrywają Uniwersytety Trzeciego Wieku. Z. Hasińska i E. Tracz ocenili je następująco:

UTW umożliwiają włączenie osób starszych do systemu kształcenia ustawicznego, proponując edukację nieformalną, nieuwieńczoną wprawdzie certyfikatami wiedzy i umiejętności, ale za to bogatszą pod względem formy i treści. Uwzględniając rangę kształcenia ogólnego oraz konieczność dostosowania treści i metod kształcenia do zmian kulturowych, edukacja ta ułatwia poszczególnym osobom własny rozwój, skutecznie przeciwdziała wykluczeniu i marginalizacji grup społecznych, przygotowuje do aktywnego i odpowiedzialnego uczestnictwa w życiu społecznym, kulturalnym, lokalnym, krajowym czy globalnym oraz do reagowania na zmiany związane z rozwojem nauki i techniki (Hasińska, Tracz 2013, s. 94-95).

Działanie Uniwersytetów Trzeciego Wieku, stale zwiększająca się liczba ich słuchaczy oraz powstawanie nowych placówek pozwalają wnioskować, iż wartość tych instytucji ma dla seniorów ogromne znaczenie. Wpływ na kształtowanie świadomości i światopoglądu starszych mają również organizacje pozarządowe, które angażują tę część społeczeństwa w różnorakie działania, zapełniając ich czas, a także wzmacniając ich potencjał i podkreślając wartość, jaką stanowią dla środowiska. Wszystkim działaniom realizowanym przez te organizacje przyświeca jeden cel: wzmocnienie pozycji i aktywności osób starszych w życiu społecznym. Zależnie od misji i zadań realizowanych w ramach stowarzyszeń czy fundacji jednostki te starają się tak dobierać metody pracy i środki aktywizujące, by miały one wymierny wpływ na życie seniorów i poprawę jego jakości. 
Nową formą, w której seniorzy mogą w realny sposób wpływać na otaczającą ich rzeczywistość, wykorzystując swój potencjał, są Społeczne Banki Czasu. Jak wskazuje K. Pędziwiatr:

Społeczny Bank Czasu jest nieformalną siecią wymiany usług, w której walutą jest czas, a jako usługę zaoferować można praktycznie wszystko. Główną zasadą pozostaje równoważność wszystkich proponowanych usług, bez względu na ich wartość rynkową - w każdej wymianie jednostką przeliczeniową jest godzina. Czas poświęcony na pomoc jednemu z uczestników można odebrać sobie u innego, dowolnie wybranego uczestnika. Do utworzenia SBC potrzeba przede wszystkim grupy osób, niekoniecznie tylko seniorów, które będą chciały wymieniać się oferowanymi przez siebie usługami. Przydatny jest przy tym dostęp do Internetu, który znacznie ułatwia organizację wymiany usług. Do funkcjonowania takiego banku jest niezbędne wzajemne zaufanie jego uczestników. Seniorzy mogą zaproponować dowolną usługę, np. naukę gotowania, pieczenia, pomoc w odrabianiu lekcji, np. w zamian za posprzątanie mieszkania, zrobienie zakupów czy skoszenie trawnika (Pędziwiatr 2015, s. 128).

Zaprezentowane w niniejszym opracowaniu rodzaje aktywności, dzięki celowemu skierowaniu do konkretnej grupy odbiorców, w sposób bezpośredni lub pośredni wpływają na jakość ich życia. Seniorzy, mogąc korzystać z tak wielu form wsparcia, chętniej niż kiedykolwiek wychodzą z domu i podejmują aktywność na rzecz rozwoju środowiska lokalnego i najbliższego otoczenia. Senior zaangażowany $\mathrm{w}$ realizowanie konkretnych zadań ma poczucie, że jest ważną częścią społecznego układu, ćwiczy i rozwija swoje umiejętności, poprawia kondycję psychofizyczną, dba o relacje interpersonalne i wypełnia czas, jaki zyskał po zakończeniu pracy zawodowej. Wszystkie te czynniki w ujęciu globalnym podnoszą jakość życia osób starszych, pozwalając cieszyć się z tego wyjątkowego okresu w życiu.

\section{ZAKOŃCZENIE}

Podsumowując rozważania, należy pamiętać, iż „Starość wieńczy życie i jest czasem żniw tego, czego się nauczyliśmy, co przeżyliśmy, co zdziałaliśmy i osiągnęliśmy, a także tego, co wycierpieliśmy i wytrzymaliśmy. Jak w końcowej partii wielkiej symfonii, te wielkie tematy współbrzmią potężnie" - jak mawiał Jan Paweł II. Kwestia jakości życia jest pojęciem wieloaspektowym, złożonym i niejednorodnym. Wpływ różnych czynników: obiektywnych i subiektywnych, indywidualnych i grupowych, makro- i mikrospołecznych, a także ich wzajemne interakcje powodują, że nie ma jednego powszechnie stosowanego modelu jakości życia. Niemniej wielką wartością jest rozwijanie tego zagadnienia w kontekście ważnych przemian społecznych. 


\section{BIBLIOGRAFIA}

Bańka A. (2005), Psychologia jakości życia, Poznań: Stowarzyszenie Psychologia i Architektura.

Baumann K. (2006), Jakość życia w okresie późnej dorostości - dyskurs teoretyczny, „Gerontologia Polska", nr 4.

Bień B. (2002), Stan zdrowia i sprawność ludzi starszych, [w:] B. Synak (red.), Polska starość, Gdańsk: Wydawnictwo Uniwersytetu Gdańskiego.

Błędowski P., Szatur-Jaworska B., Szweda-Lewandowska Z., Kubicki P. (2012), Raport na temat sytuacji osób starszych w Polsce, Warszawa: Instytut Pracy i Spraw Socjalnych.

Car J., Sygnowski T., Gębska-Kuczerowska A., Wysocki M.J. (2004), Epidemiologia niepetnosprawności w podeszłym wieku. Materiały konferencyjne, Warszawa: PTG.

Chabior A. (2014a), Aktywność i aktywizacja osób starszych, [w:] A. Chabior, A. Fabiś, J.K. Wawrzyniak, Starzenie się i starość w perspektywie pracy socjalnej, Warszawa: Centrum Rozwoju Zasobów Ludzkich.

Chabior A. (2014b), Rodzina i jej znaczenie w życiu ludzi starszych, [w:] A. Chabior, A. Fabiś, J.K. Wawrzyniak, Starzenie się i starość w perspektywie pracy socjalnej, Warszawa: Centrum Rozwoju Zasobów Ludzkich.

Chabior A., Fabiś A., Wawrzyniak J.K. (2017), Ludzka starość. Wybrane zagadnienia gerontologii społecznej, Kraków: Oficyna Wydawnicza „Impuls”.

Dzięgielewska M. (2006), Aktywność społeczna i edukacyjna w fazie starości, [w:] B. Szatur-Jaworska, P. Błędowski, M. Dzięgielewska, Podstawy gerontologii społecznej, Warszawa: Aspra.

Dziurowicz-Kozłowska A. (2002), Wokół pojęcia jakości życia, „Psychologia Jakości Życia”, nr 1.

Halicka M., Halicki J. (2002), Integracja społeczna i aktywność ludzi starszych, [w:] B. Synak (red.), Polska starość, Gdańsk: Wydawnictwo Uniwersytetu Gdańskiego.

Hasińska Z., Tracz E. (2013), Rola uniwersytetów trzeciego wieku w aktywnym starzeniu się, „Nauki Społeczne", nr 7.

Kaczmarczyk M., Trafiałek E. (2007), Aktywizacja osób w starszym wieku jako szansa na pomyślne starzenie, „Gerontologia Polska” 2007, nr 4.

Kocemba J. (2000), Biologiczne wyznaczniki starości, [w:] Z. Szarota, A. Panek (red.), Zrozumieć starość, Kraków: TEST.

Kotlarska-Michalska A. (2000), Starość w aspekcie socjologicznym, „Rocznik Socjologii Rodziny”, nr 12.

Kutyła M. (2012), Integracja społeczna ludzi starszych, [w:] N. Pikuła (red.), Starość może być atrakcyjna, Kraków: Wydawnictwo „Scriptum”.

Osińska K. (1980), Twórcza obecność chorych, Warszawa: Pax.

Pędich W. (1996), Ludzie starzy, Warszawa: CRSS.

Pędziwiatr K. (2015), Aktywizacja społeczna osób starszych w Polsce, [w:] A. Janiszewska (red.), Jakość życia ludzi starych - wybrane zagadnienia, Łódź: Wydawnictwo Uniwersytetu Łódzkiego.

Skrzypek E. (2001), Czynniki ksztattujące jakość życia, http://idn.org.pl/Lodz/Mken/Mken\%20 2001/Referaty\%202001/14.pdf (dostęp: 20.09.2018). 
Steuden S. (2014), Psychologia starzenia się i starości, Warszawa: PWN.

Szyszkowska M. (2014), Znaczenie ludzi sędziwych, [w:] A. Zych (red.), Starość darem, zadaniem i wyzwaniem, Sosnowiec-Dąbrowa Górnicza: Stowarzyszenie Przyjaciół Domu Pomocy Społecznej „Pod Dębem” w Dąbrowie Górniczej.

The World Health Organization Quality of Life assessment (WHOQOL): position paper from the World Health Organization (1995), "Social Science \& Medicine", Vol. 41(10).

Wawrzyniak J.K. (2017), Starzenie się i jego charakterystyka, [w:] A. Chabior, A. Fabiś, J.K. Wawrzyniak (red.), Ludzka starość. Wybrane zagadnienia gerontologii społecznej, Kraków: Oficyna Wydawnicza „Impuls”.

Wieczorowska-Tobis K. (2011), Specyfika pacjenta starszego, [w:] K. Wieczorowska-Tobis, T. Kostka, A. Borowicz (red.), Fizjoterapia w geriatrii, Warszawa: Wydawnictwo Lekarskie PZWL.

Wilmowska-Pietruszyńska A. (2012), Niepetnosprawność i niezdolność do samodzielnej egzystencji, [w:] J. Hrynkiewicz (red.), O sytuacji ludzi starszych, Warszawa: Rządowa Rada Ludnościowa, Zakład Wydawnictw Statystycznych.

Zych A. (red.) (2014), Starość darem, zadaniem i wyzwaniem, Sosnowiec-Dąbrowa Górnicza: Stowarzyszenie Przyjaciół Domu Pomocy Społecznej „Pod Dębem” w Dąbrowie Górniczej.

\section{SUMMARY}

Europe has a great social challenge. Seniors in the social landscape are its inseparable and an important element, but never before have they formed such a large group. That is why the quality of life of older people has become such an important challenge. The article is a voice in the discussion about the aging society and the quality of life of seniors. This text aims to approximate the importance of quality of life and the analysis of individual elements such as health, contacts with families, active participation in social life, opportunities for development or the ability to implement their own plans and objectives, taking into account the needs, opportunities and values of older people. The subject matter is the voice in the shaping social image, it is a contribution to supplementing pragmatic knowledge about the functioning of older people. Seniors, thanks to their experience and values passed on to younger generations, are huge capital with invaluable resources: knowledge, wisdom and skills. The detailed characteristics of selected elements that create the quality of life will allow a more comprehensive understanding and take steps to optimize the quality of life of the older generation.

Keywords: senior; gerontology; quality of life; aging 